\title{
Characterization of a Novel Mannose-Binding Lectin with Antiviral Activities from Red Alga, Grateloupia chiangii
}

\author{
Hyun-Ju Hwang ${ }^{1}$, Jin-Wook Han ${ }^{1}$, Hancheol Jeon ${ }^{1}$, Kichul Cho ${ }^{1}$, Ju-hee Kim ${ }^{2}$, Dae-Sung Lee ${ }^{3}$ \\ and Jong Won Han $1, * \mathbb{B}$ \\ 1 Department of Applied Bioresource Science, National Marine Biodiversity Institute of Korea, Seocheon \\ 33662, Korea; hjhwang@mabik.re.kr (H.-J.H.); hiclow@mabik.re.kr (J.-W.H.); hjeon@mabik.re.kr (H.J.); \\ win0830ner@naver.com (K.C.) \\ 2 Department of Ecology and Conservation, National Marine Biodiversity Institute of Korea, Seocheon 33662, \\ Korea; algae2030@mabik.re.kr \\ 3 Department of Genetic Resources Research, National Marine Biodiversity Institute of Korea, Seocheon 33662, \\ Korea; daesung@mabik.re.kr \\ * Correspondence: jwhan@mabik.re.kr; Tel.: +82-41-950-0760
}

Received: 31 December 2019; Accepted: 17 February 2020; Published: 19 February 2020

\begin{abstract}
Lectins have the ability to bind specific carbohydrates and they have potential applications as medical and pharmacological agents. The unique structure and usefulness of red algal lectin have been reported, but these lectins are limited to a few marine algal groups. In this study, a novel mannose-binding lectin from Grateloupia chiangii (G. chiangii lectin, GCL) was purified using antiviral screens and affinity chromatography. We characterized the molecular weight, agglutination activity, hemagglutination activity, and heat stability of GCL. To determine the carbohydrate specificity, a glycan microarray was performed. GCL showed strong binding affinity for Maltohexaose- $\beta$-Sp1 and Maltoheptaose- $\beta$-Sp1 with weak affinity for other monosaccharides and preferred binding to high-mannan structures. The N-terminal sequence and peptide sequence of GCL were determined using an Edman degradation method and LC-MS/MS, and the cDNA and peptide sequences were deduced. GCL was shown to consist of 231 amino acids $(24.9 \mathrm{kDa})$ and the N-terminus methionine was eliminated after translation. GCL possessed a tandem repeat structure of six domains, similar to the other red algal lectins. The mannose binding properties and tandem repeat structure of GCL may confer it the potential to act as an antiviral agent for protection against viral infection.
\end{abstract}

Keywords: lectin; Grateloupia; algae; hemagglutination; antiviral

\section{Introduction}

Lectin, discovered more than 100 years ago, is defined as a carbohydrate binding protein [1]. Lectin has the ability to agglutinate erythrocytes by recognizing specific carbohydrate chains on the surface of the cells, also referred to as agglutinins or hemagglutinins [2]. Lectins are widely distributed throughout bacteria, plants, and animals. They act as defensive molecules in plants by recognizing pathogenic organisms [3]. It has also been suggested that lectin is a defensive substance innate to the immune system of vertebrates and invertebrates [4]. Furthermore, lectin is related to a variety of other biological processes such as cell development, cell-cell interactions, and signaling pathways [5].

Because of the carbohydrate binding properties of lectins and their involvement in the defensive system and immune response of organisms, lectin has seen diverse applications in biological research and pharmacology [6-8]. For instance, the fluorescent lectins, combined with several other techniques, have been widely used to analyze the surface carbohydrates of cells or organelles [9]. Also, lectin 
immobilized matrices for glycoprotein isolation have become a common tool in glycobiology [10] and lectin micro-arrays have become popular tools for cell carbohydrate profiling [11]. Within the last decade, pharmacological applications of lectins have been reported [12], including those with anti-cancer (or anti-tumor) and anti-viral effects $[13,14]$. Because of lectins' ability to specifically recognize cell surface carbohydrates, it has potential to grant specificity to drug delivery systems or to aid in diagnoses [15].

Algal lectins exhibit unique carbohydrate specificity and physico-chemical characteristics when compared to other plant lectins [16]. Lectins, including algal lectin, are able to bind and recognize a wide range of pathogens, including fungi, bacteria, viruses, and parasites, leading to agglutination and neutralization of these microorganisms [17]. For this reason, algal lectins have long been believed to have extraordinary potential for medical applications such as anti-tumor, anti-viral, and anti-microbial effects $[16,17]$.

Algal lectins have been found in the green, brown, and red algal groups. Approximately $60 \%$ of algal lectins have come from Rhodophyta (red algae) [16] and the biomedical potential of lectins from these algae has been reported [17]. To date, about 500 lectins from red algae have been screened, but less than 40 lectins have been purified and sequenced [18]. Among the purified red algal lectins, few have had their pharmacological applications discussed or confirmed (i.e., Griffithsin) $[19,20]$. Although the role of lectins in red algae remains unclear, several roles have been suggested, including an involvement in spermatia and tricogyne mutual recognition in sexual reproduction [21,22].

Several red algal lectins possess a unique repeated primary structure [18] and the contribution of this tandem repeat structure to lectin activity was elucidated by recombinant technology $[18,23]$. These studies revealed that the primary structure of red algal lectin contributes to the production of lectin by recombinant proteins. Therefore, more information on red algal lectin is needed for deeper study. Among the diverse array of lectins, mannose-binding lectin (belonging to the collectin, or C-type pattern recognition lectins) is a popular choice for studies that focus on antivirals or viral infection pathways. The relevance of mannose receptors in viral infections has been reported [13,24], and implies the importance of mannose-binding lectins in the development of antiviral agents. Mannose-binding lectin was able to interrupt the self-assembly of viruses during viral replication [25], and has risen as a potential candidate for anti-viral agents in the form of high-dose mannose-binding lectin therapy against Ebola [26].

Griffithsin from Griffithsia sp. is a good example of a red algal lectin with therapeutic potential. Since the discovery of Griffithsin by Watson and Waaland [27], this protein has been widely studied with thousands of articles being published on it [28], putting red algal lectin in the spotlight. Griffithsin has specificity for mannose and possesses antiviral activity against HIV-1 [19,28] and Hepatitis C viral infections [29]. Although there are many reports that suggest the therapeutic potential of algal lectin, few lectins have had their biomedical properties and biological functions elucidated because of limited quantities or information. Thus, the accumulation of biological information for a variety of lectins is necessary.

In this study, a novel red algal lectin from Grateloupia chianggi was purified and partially characterized. Additionally, preliminary studies on the antiviral activity of G. chianggi lectin (GCL) were performed, leading to the discussion of potential applications for G. chianggi lectin in biochemical and medical research.

\section{Materials and Methods}

\subsection{Algal Sources}

Red alga G. chianggi was collected from the southern coast of Korea. Collected samples were cleaned twice with autoclaved sea-water and moisture was removed by a paper towel. The cleaned samples were stored at $-80^{\circ} \mathrm{C}$ until use. 


\subsection{Purification of GCL}

The crude extract was prepared according to previous methods [30]. An algal sample (30 g) was immersed in liquid nitrogen and ground to a fine powder with a mortar and pestle. Five volumes of extraction buffer (Tris-buffered saline (TBS): $20 \mathrm{mM}$ Tris-Cl, $150 \mathrm{mM} \mathrm{NaCl}, \mathrm{pH}$ 7.5) were added to the sample to prepare the crude extract. The sample was incubated for $2 \mathrm{~h}$ at $4{ }^{\circ} \mathrm{C}$, centrifuged at 20,000 $\times \mathrm{g}$ for $20 \mathrm{~min}$ at $4{ }^{\circ} \mathrm{C}$ and then the supernatant was collected as the crude extract. Then, D-mannose (Man) chromatography was immediately performed on the crude extract using a Bio-rad fast protein liquid chromatography system (Bio-rad, Berkeley, CA, USA). The column was washed with 10 volumes of TBS. Mannose-binding proteins were eluted with $0.5 \mathrm{M}$ D-mannose with an extraction buffer by monitoring the absorbance at $280 \mathrm{~nm}$. The fractions showing single bands following sodium dodecyl sulfate-polyacrylamide gel electrophoresis (SDS-PAGE) were fooled. The purified protein was dialyzed in TBS buffer overnight with buffer changes every $4 \mathrm{~h}$. The total protein and purified protein concentrations were measured by a Bradford micro-assay [31] using an enzyme-linked immunosorbent assay (ELISA) reader (Epoch microplate spectrophotometer, BioTek, Winooski, VT, USA).

\subsection{Partial Characterization of Lectin}

The presence of inter- and intra-molecular disulfide bonds was determined by SDS-PAGE with the absence or presence of reductant DTT (1,4-dithiothreitol) in sample buffer. Protein stability at various temperatures was measured following previous methods [30]. The purified lectin was divided into $500 \mu \mathrm{L}$ aliquots in microtubes. The water bath for testing was set to seven different temperatures, $30{ }^{\circ} \mathrm{C}, 40{ }^{\circ} \mathrm{C}, 50^{\circ} \mathrm{C}, 60^{\circ} \mathrm{C}, 70{ }^{\circ} \mathrm{C}, 80^{\circ} \mathrm{C}$, and $90^{\circ} \mathrm{C}$. Samples stored at room temperature were used as control. Samples were incubated at the designated temperature for $30 \mathrm{~min}$, then removed and cooled to room temperature, followed by centrifugation at 12,000 $\mathrm{g}$ for $10 \mathrm{~min}$ to remove the insoluble materials produced during incubation. The supernatant was collected and used immediately in hemagglutination assays. The effect of divalent metal ions was determined by adding $5 \mathrm{mM} \mathrm{MgCl}$ and $\mathrm{CaCl}_{2}$, or the absence of divalent metal ions in the protein solution.

\subsection{Hemagglutination Assay and Carbohydrate Specificity}

Horse and sheep blood for the hemagglutination assay were purchased from Hanil Comed (Sungnam, Gyeonggi-do, Korea). Blood was washed with phosphate buffered saline (PBS, pH 7.3) until the red color of the supernatant disappeared. Erythrocytes were prepared to a $4 \%$ suspension in PBS. The lectin samples were serially diluted in a 96 -well U bottom plate and then the $4 \%$ erythrocyte suspension was added to each well. After incubation at room temperature for $30 \mathrm{~min}$, hemagglutination activity was judged.

Carbohydrate specificity was measured by a hemagglutination inhibition test. The following carbohydrates and glycoproteins were used for the inhibition test; D-glucose (Glc), D-mannose, D-galactose (Gal), N-acetyl-D-glucosamine (GlcNAc), N-acetyl-D-galactosamine, L-fucose, fructose, lactose, and bovine fetuin. Samples $(25 \mu \mathrm{L})$ that have four hemagglutination activities, were mixed with each carbohydrate $(25 \mu \mathrm{L})$ and $25 \mu \mathrm{L}$ of mixture was removed from the well. An equal volume of $4 \%$ horse erythrocyte suspension was added to the sample and mixed. The plates were incubated at room temperature for $30 \mathrm{~min}$ and inhibition was measured.

\subsection{Determination of N-Terminal Amino Acid Sequences}

$\mathrm{N}$-terminal amino acid sequences were determined by the Korea Basic Science Institute (KBSI, Seoul, Korea). Protein bands were transferred to polyvinylidene difluoride membranes using a Western blot kit (Bio-rad, USA). Membranes were stained with ponsiue $S$ staining solution. Single bands on the membrane were excised using a knife and sent to KBSI. N-terminal sequencing was performed using a Procise $491 \mathrm{HT}$ protein sequencer (Applied Biosystems). 


\subsection{Peptide Mapping Using Mass Spectrometry}

Peptide mapping was performed according to previous methods [23]. Protein bands obtained from SDS-PAGE were excised, in-gel digested with trypsin, and cleaned with Zip-Tip (Millipore, Billerica, MA, USA). Mass spectrometry analyses were performed using Capillary LC-Nano ESI-MS with a 6545 Q-TOF LC/MS (Agilent Technologies, Santa Clara, CA, USA). Samples were applied to a ZORBAX 300SB-C8 column $(1 \times 50 \mathrm{~mm}, 3.5 \mu \mathrm{m}$; Agilent $)$ equilibrated with $0.1 \%(v / v)$ formic acid in mass grade water and eluted by a gradient between water and $100 \%$ acetonitrile at a flow rate of $10 \mu \mathrm{L} / \mathrm{min}$. The tuning parameters used for mass analyses were as follows: capillary temperature 300 ${ }^{\circ} \mathrm{C}$, source voltage $1.9 \mathrm{kV}$, skimmer voltage $45 \mathrm{~V}$, and fragmentor voltage $175 \mathrm{~V}$.

\subsection{Cloning of GCL and Determination of $c D N A$ Sequences}

Based on the N-terminal sequencing and peptide mapping results, the cDNA sequence was screened with transcriptome data (generated by Hi-seq 3000 ). The full cDNA sequence was confirmed by PCR. Total RNA was obtained using a Qiagen Plant total RNA isolation kit following the manufacture's protocol. The quality of total RNA was determined using a spectrophotometer and formaldehyde agarose gel electrophoresis. First strand cDNA was synthesized with oligo-dT primers using a cDNA synthesis kit from Promega (Madison, WI, USA). cDNA was purified using an Intron PCR purification kit and immediately used for PCR. PCR primers were designed based on transcriptome data and $\mathrm{N}$-terminal sequencing results (Table 1). The PCR reaction was performed as follows: $95^{\circ} \mathrm{C} 2 \mathrm{~min}$ for pre-denaturation, 35 cycles of $95^{\circ} \mathrm{C}$ for $20 \mathrm{~s}, 60^{\circ} \mathrm{C}$ for $30 \mathrm{~s}, 72{ }^{\circ} \mathrm{C}$ for $1 \mathrm{~min}$, and then the final reaction was performed at $72{ }^{\circ} \mathrm{C}$ for $10 \mathrm{~min}$. The PCR product was loaded onto agarose gel for electrophoresis and the target band was excised with a sharp knife. The PCR product was purified using a gel elution kit following the manufacture's protocol. The isolated PCR product was cloned into a T-easy cloning vector and transformed into host $\mathrm{DH} 5 \alpha$. The transformant was plated on a Luria-Bertani agar plate containing $100 \mu \mathrm{g} / \mathrm{mL}$ of ampicillin and incubated at $37^{\circ} \mathrm{C}$ overnight. After incubation, positive colonies were collected and cultured in Luria-Bertani broth at $37^{\circ} \mathrm{C}$ overnight.

Table 1. Primers for amplification of Grateloupia chianggi lectin (GCL).

\begin{tabular}{ccc}
\hline Name & Sequence (5' ${ }^{\prime} \mathbf{3}^{\prime}$ ) & Purpose \\
\hline GCL-1 & GGNGARTGYYTNCAYCG & \\
GCL-2 & GGNGARTGYYTNCAYAG & \\
GCL-3 & GTNTCNGGNGARTGYCT & \\
GCL-4 & GTNAGYGGNGARTGYCT & \\
GCL-5 & GTNGTNTCNAAYCGNCT & \\
GCL-6 & GTNGTNTCNAAYCGNTT & \\
GCL-7 & GTNGTNTCNAAYAGTCT & \\
GCL-8 & GTNGTNTCNAAYAGTRTT & \\
DPP & GGTGAATGCTGCGACTACGATCCCCCTTTTTTTTTTTTTTTT & For the full length GCL gene \\
GCL-F & ATGGTTGTCTCCAACAGAC & For the full length GCL gene \\
GCL-R & CGTATTGGTAGCCCAG & \\
\hline
\end{tabular}

Plasmids were isolated using a plasmid isolation kit (Qiagen, Hilden, Germany). The DNA was sequenced by the Sanger based method (Macrogen, Seoul, Korea).

\subsection{Glycan Microarray}

A glycan microarray analysis was performed by Ebiogen (Seoul, Korea) according to previous methods [23]. The Glycan Array kit was purchased from RayBioTech (Norcross, GA, USA). An array containing 300 synthetic glycans printed in quadruplicate on a glass slide was used. Label-based detection was performed according to the manufacturer's protocols and previous methods [23]. Biotinylated recombinant lectins and native lectins at $50 \mu \mathrm{g} / \mathrm{mL}$ were added to the array wells and incubated for $>3 \mathrm{~h}$ with gentle rocking. The glass slide was washed with $1 \times$ wash buffer I and II, provided in the kit. Glycan-lectin binding was detected by incubation with Cy3 equivalent 
dye-conjugated streptavidin for $1 \mathrm{~h}$ at room temperature. For cyanine-3 detection, the signals were visualized using a microarray laser scanner (GenePix 4100A; Molecular Devices, Sunnyvale, CA, USA) with excitation at $554 \mathrm{~nm}$ and emission at $568 \mathrm{~nm}$. Data extraction was performed using the microarray analysis software, GenePix Pro (ver. 7.2, Sunnyvale, CA, USA). Glycan array data were normalized and analyzed using RayBio Analysis software (RayBioTech, GA-Glycan-300-SW, Norcross, GA, USA).

\subsection{Antiviral Activity Test}

Antiviral assays were performed at the Center for Convergent Research of Emerging Virus Infection at the Korea Research Institute of Chemical Technology (Daejeon, Korea) following previous protocols [32].

Madin-Darby canine kidney (MDCK) cells from the American Type Culture Collection (ATCC, Manassas, VA, USA), African green monkey kidney Vero cells (ATCC), and HTLV-1-infected human T lymphocyte MT-4 cells were used for antiviral assays against the influenza virus, herpes simplex virus (HSV), and human immunodeficiency virus (HIV), respectively. MDCK cells were grown in minimum essential medium (Gibco/Invitrogen, Carlsbad, CA, USA) supplemented with 10\% fetal bovine serum (Invitrogen) at $37^{\circ} \mathrm{C}$. Vero cells were grown at $37^{\circ} \mathrm{C}$ in Dulbecco's modified Eagle's medium (Gibco/Invitrogen) supplemented with 10\% fetal bovine serum (Invitrogen).

Influenza virus strains, A/Puerto Rico/8/34 (H1N1) (PR8), A/Hong Kong/8/68 (H3N2) (HK), and $\mathrm{B} /$ Lee/1940 (B) were obtained from ATCC and propagated in 10-day-old chicken embryos at $37^{\circ} \mathrm{C}(\mathrm{PR} 8$ and $\mathrm{HK}$ ) or MDCK cells at $35^{\circ} \mathrm{C}$ (B) for 3 days. For the anti-HSV assay, the HSV1 strain F and HSV strain MS were used. HIV1 strain IIb and HIV2 strain ROD was used for the anti-HIV assay. Antiviral assays were performed based on the virus-induced cytopathic effect (CPE reduction assay).

In the anti-influenza viral assay, MDCK cells were seeded onto 96-well plates and either mock-infected or infected with influenza virus at a multiplicity of infection of 0.001 (50 plaque-forming units of influenza virus per well). After incubation for $1 \mathrm{~h}$ at $35{ }^{\circ} \mathrm{C}(\mathrm{PR} 8, \mathrm{BB}$, and $\mathrm{HK}$ ), the medium was removed, and GCL was added and subsequently serially diluted in minimum essential medium containing TPCK (L-1-Tosylamide-2-phenylethyl chloromethyl ketone)-trypsin (Sigma). On day 2 or 3 post-infection, cell viability was analyzed with an MTT [3-(4,5-dimethylthiazol-2-yl)-2,5-diphenyltetrazolium bromide] assay. In the anti-HSV assay, HSV infected or non-infected Vero cells were incubated for 3 days and then cell viability was measured by an MTT assay. In the anti-HIV assay, MT-4 cells were centrifuged and the supernatant was removed, and the harvested cells were infected by HIV. Mock-infected cells were added with RPMI 1640/10\% in place of HIV as a control. Cells were diluted to $1 \times 10^{5}$ cells $/ \mathrm{mL}$. The cells were incubated at $37^{\circ} \mathrm{C}$ in a $\mathrm{CO}_{2}$ incubator for 5 days. Cell viability was measured by an MTT assay.

The $50 \%$ cytotoxic concentration $\left(\mathrm{CC}_{50}\right)$ and the $50 \%$ effective concentration $\left(\mathrm{EC}_{50}\right)$ values were calculated using SoftMax Pro Software (Pro 7, Molecular Devices, Sunnyvale, CA, USA).

\section{Results}

\subsection{Purification of Mannose-Binding Lectin}

GCL was successfully purified using mannose affinity chromatography. Single protein bands were observed from isolated fractions without any impurities (Figure 1). The molecular weight of GCL was $\sim 25 \mathrm{kDa}$ as determined by SDS-PAGE (Figure 1). Approximately $13.8 \mathrm{mg}$ of protein were extracted from $30 \mathrm{~g}$ of $\mathrm{G}$. chiangii (wet weight). A total of $0.65 \mathrm{mg}$ of GCL was obtained from $30 \mathrm{~g}$ of $\mathrm{G}$. chiangii, accounting for $4.7 \%$ of all proteins and the specific agglutination activity was 51,200 (titer/mg). Purification increased 14.72-fold (Table 2). 


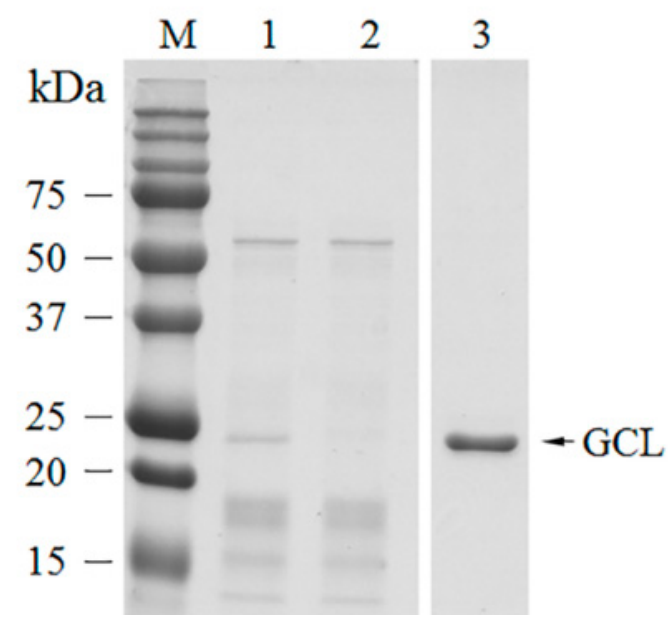

Figure 1. Purification of Grateloupia chianggi lectin (GCL) using D-mannose affinity chromatography. $\mathrm{M}=$ molecular weight marker; 1 = crude extract lane; 2 = flow-through fraction lane; 3 = purified GCL lane.

Table 2. Purification of Grateloupia chianggi lectin (GCL) from $30 \mathrm{~g}$ of G. chiangii. Hemagglutination activity was determined using horse erythrocytes.

\begin{tabular}{ccccccc}
\hline Condition & $\begin{array}{c}\text { Total } \\
\text { Protein }(\mathbf{m g})\end{array}$ & $\begin{array}{c}\text { Concentration } \\
\mathbf{( m g / m L )}\end{array}$ & $\begin{array}{c}\text { Total } \\
\text { Activity } \\
\text { (Titer) }\end{array}$ & $\begin{array}{c}\text { Specific } \\
\text { Activity } \\
\text { (Titer/mg) }\end{array}$ & $\begin{array}{c}\text { Percentage } \\
\text { of Recovery }\end{array}$ & $\begin{array}{c}\text { Purification } \\
\text { Fold }\end{array}$ \\
\hline $\begin{array}{c}\text { Crude Extract } \\
\begin{array}{c}\text { Affinity } \\
\text { Chromatography }\end{array}\end{array}$ & 13.8 & 0.092 & 48,000 & 3478 & 100 & 1.00 \\
\hline
\end{tabular}

\subsection{Molecular Properties and Cloning of GCL}

The sequence of the N-terminal amino acids of GCL was determined to be Val-Val-Ser-Asn-Arg-Lue-Val-Ser-Gly-Glu-X-Leu-His-Arg from Edman degradation analysis. The full-length cDNA sequence was determined by PCR combined with transcriptome data generated by a Hi-seq 2000 sequencer. The cDNA consisted of $900 \mathrm{bp}$ including $696 \mathrm{bp}$ of open reading frame. The calculated molecular weight of the protein was $24.9 \mathrm{kDa}$ and the theoretical isoelectric point was pI 6.97, which corresponded to SDS-PAGE data. In total, mass data from nine peptides were obtained from LC-MS/MS data that covered about $70 \%$ of the protein sequence. The peptide mapping data and $\mathrm{N}$-terminal sequencing result were consistent with the predicted peptide mass. The $\mathrm{N}$-terminal methionine was removed by post transcriptional modification according to comparisons between data from the intact $\mathrm{N}$-terminal sequence (Figure S1).

Interestingly, GCL possessed a tandem repeat structure that contained six repeat domains of 30-mer (Figure S2). GCL was determined to be a member of the B class lectins and possessed similarity to bacterial mannose-binding lectins. The mannose binding sites and dimerization interface were well conserved (Figure S3). However, similar proteins from plants or algae could not be identified using a GenBank database.

\subsection{Hemagglutination Activity and Carbohydrate Specificity}

GCL agglutinated horse erythrocytes but not sheep erythrocytes. The minimum concentration of GCL for agglutination of horse erythrocytes was $0.8 \mu \mathrm{g} / \mathrm{mL}$ (Figure 2A). 
(A)

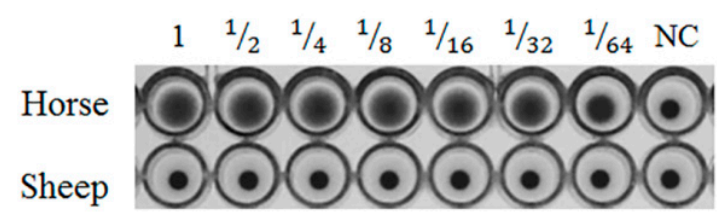

(B)

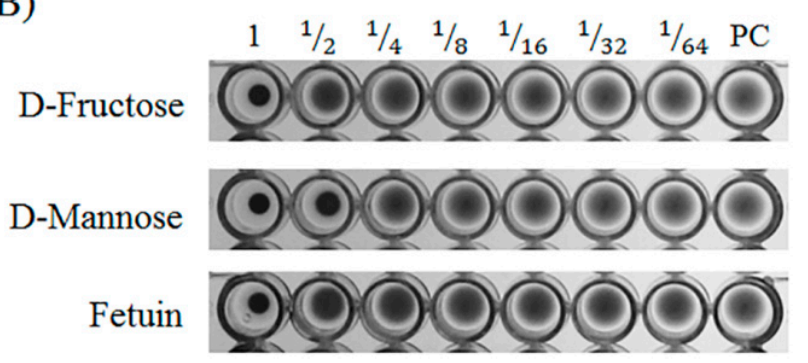

Figure 2. Hemagglutination assay and carbohydrate specificity of Grateloupia chianggi lectin (GCL). (A) Hemagglutination activity of GCL $(25 \mu \mathrm{g} / \mathrm{mL})$ in horse and sheep blood. (B) Carbohydrate specificity of GCL (four hemagglutination activity units of GCL were used for the inhibition test). A serial two-fold dilution was obtained (left to right); NC, negative control; PC, positive control.

Inhibition experiments were performed with ten different carbohydrates to determine specificity. The hemagglutination activity of GCL was inhibited by the monosaccharides, D-mannose and fructose at $125 \mathrm{mM}$ and $250 \mathrm{mM}$, respectively. The hemagglutination activity was also inhibited by the glycoprotein fetuin at $195 \mu \mathrm{g} / \mathrm{mL}$. The other carbohydrates tested were unable to inhibit activity (Figure 2B, Table 3).

Table 3. Minimum inhibitory concentration of lectin by treatment of various substances.

\begin{tabular}{cc}
\hline Substance & Concentration $(\mathbf{m M})$ \\
\hline D-Glucose & $\mathrm{NI}{ }^{*}$ \\
D-Galactose & $\mathrm{NI}$ \\
D-Mannose & 125 \\
N-Acetyl-D-Glucosamine & $\mathrm{NI}$ \\
N-Acetyl-D-Galactosamine & $\mathrm{NI}$ \\
L-Fucose & $\mathrm{NI}$ \\
Maltose & $\mathrm{NI}$ \\
Lactose & $\mathrm{NI}$ \\
Fructose & 250 \\
Fetuin & $195^{* *}$
\end{tabular}

* NI, absence of inhibition at $250 \mathrm{mM} .{ }^{* *} 195 \mu \mathrm{g} / \mathrm{mL}$ (due to unidentified molecular weight).

\subsection{Effect of Temperature and Divalent Ions on GCL}

Heat stability of GCL was measured at various temperatures $\left(20-90^{\circ} \mathrm{C}\right)$. GCL activity was not affected until $30^{\circ} \mathrm{C}$. Half of activity was lost at $40{ }^{\circ} \mathrm{C}$. Interestingly, about $15 \%$ of the original activity was maintained even after being subjected to $90^{\circ} \mathrm{C}$ heat for $30 \mathrm{~min}$ (Figure 3A). The activity of GCL was not significantly affected by the presence of divalent cations as the addition of the divalent cations, $\mathrm{Mg}^{2+}$ or $\mathrm{Ca}^{2+}$, did not increase the GCL activity (Figure 3B). 
(A)

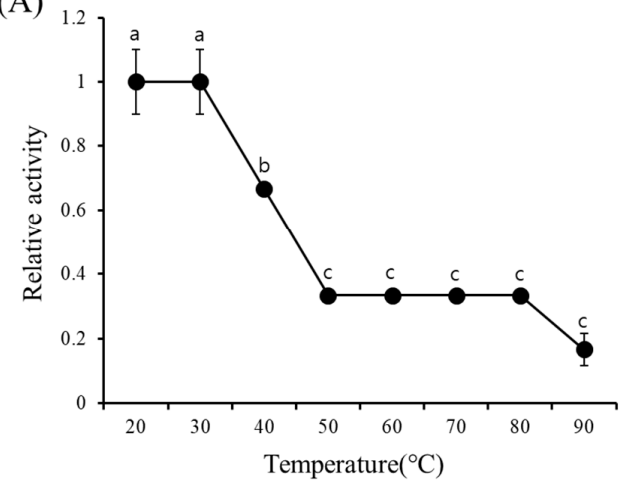

(B)

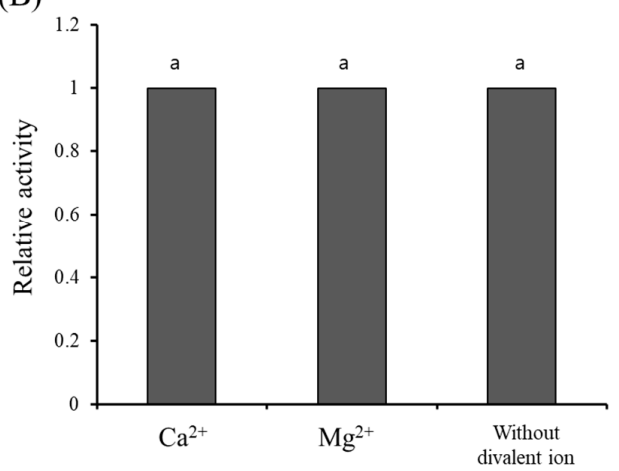

Figure 3. Activity of Grateloupia chianggi lectin (GCL) at various temperatures and in the presence of divalent ions. (A) Effect of temperatures on GCL activity. (B) Effect of the presence or absence of divalent ions, $\mathrm{n}=3$. Error bars represent mean \pm standard deviation of triplicate experiments and different letters indicate significant difference $(p<0.05)$.

\subsection{Glycan Micro-Array}

In order to determine the carbohydrate specificity, a glycan micro-array was performed which immobilized 300 different carbohydrates (Table S1). Positive signals over 1000 were observed in 18 of the 300 tested carbohydrates (Figure 4, Table 4). GCL demonstrated weak binding affinity for the monosaccharides, $\beta$-Glc-sp, $\beta$-Gal-sp, and $\alpha$-Man-sp with normalized signal intensities of 2579, 2269, and 2194, respectively. GLC also exhibited binding affinity for Maltotetraose- $\beta$-Sp1 with a signal intensity of 2705 . GCL possessed a strong binding affinity for Maltohexaose- $\beta$-Sp1 and Maltoheptaose- $\beta$-Sp1. The protein also exhibited weak binding affinity for N-glycan (signal intensity of 1000). The high-mannan structures, i.e., Man- $\alpha$-1,6-(Man- $\alpha$-1,3-)Man- $\alpha$-1,6-(GlcNAc- $\beta$-1,2-Man- $\alpha-1,3-)$ Man- $\beta-1,4-G l c N A c-\beta-1,4-G l c N A c-S p 5$ were also shown to interact with GCL (Figure 4).

Table 4. Overview of carbohydrate structures recognized by Grateloupia chianggi lectin (GCL).

\begin{tabular}{|c|c|c|}
\hline \multirow{2}{*}{ No. } & \multirow{2}{*}{ Glycan Structure } & \multirow{2}{*}{$\frac{\text { RFU (Normalized) }}{\text { GCL }}$} \\
\hline & & \\
\hline \multicolumn{3}{|c|}{ Monosaccharides } \\
\hline G0001 & $\beta$-Glc-Sp & $2273 \pm 544$ \\
\hline G0002 & $\beta-$ Gal-Sp & $2165 \pm 237$ \\
\hline G0003 & $\alpha-M a n-S p$ & $2093 \pm 294$ \\
\hline G0006 & $\beta-G l c N A c-S p$ & $1104 \pm 133$ \\
\hline \multicolumn{3}{|c|}{ Disaccharides } \\
\hline G0016 & Gal- $\beta-1,4-$ Glc- $\beta-S p$ & $1260 \pm 126$ \\
\hline G0048 & Glc- $\alpha-1,2-G a l-\alpha-S p$ & $1173 \pm 110$ \\
\hline G0076 & Glc- $\alpha-1,4-G l c-\beta-S p 1$ & $1238 \pm 28$ \\
\hline G0087 & D-cellulose- $\beta$-Sp1 & $1165 \pm 82$ \\
\hline \multicolumn{3}{|c|}{ Globo series, Milk Oligosaccharides, and GAGs } \\
\hline G0018 & Gal- $\alpha-1,4-$ Gal- $\beta-1,4-$ Glc- $\beta$-Sp & $1124 \pm 47$ \\
\hline G0020 & GalNAc- $\beta-1,3-$ Gal- $\beta-1,4-$ Glc- $\beta-S p$ & $1092 \pm 92$ \\
\hline \multicolumn{3}{|c|}{ Amino Glycoside } \\
\hline G0056 & Sisomicin sulfate & $1583 \pm 177$ \\
\hline \multicolumn{3}{|c|}{ Natural Oligosaccharides } \\
\hline G0080 & Maltotetraose- $\beta$-Sp1 & $2577 \pm 351$ \\
\hline G0082 & Maltohexaose- $\beta-S p 1$ & $7524 \pm 1976$ \\
\hline G0083 & Maltoheptaose- $\beta-S p 1$ & $8132 \pm 1810$ \\
\hline \multicolumn{3}{|c|}{ N-glycans } \\
\hline $\mathrm{N}-010$ & Man- $\alpha-1,6-($ Man- $\alpha-1,3-)$ Man- $\alpha-1,6-(G l c N A c-\beta-1,2-$ Man- $\alpha-1,3-)$ Man- $\beta-1,4-G l c N A c-\beta-1,4-G l c N A c-S p 5$ & $1142 \pm 116$ \\
\hline N-011 & $\begin{array}{c}\text { Man- } \alpha-1,6-(\text { Man- } \alpha-1,3-) \text { Man- } \alpha-1,6-(G a l-\beta-1,4-G l c N A c-\beta-1,2-M a n-\alpha-1,3-) \text { Man- } \beta-1,4- \\
\text { GlcNAc- } \beta-1,4-\text {-GlcNAc-Sp5 }\end{array}$ & $1148 \pm 173$ \\
\hline N-014 & $\begin{array}{c}\text { Man- } \alpha-1,6-(\text { Man- } \alpha-1,3-) \text { Man- } \alpha-1,6-[\text { Gal- } \beta-1,4-(\text { Fuc- } \alpha-1,3-) \text { GlcNAc- } \beta-1,2-M a n- \\
\alpha-1,3-] \text { Man- } \beta-1,4-\text {-GlcNAc- } \beta-1,4-G \text {-GlcNAc-Sp5 }\end{array}$ & $1129 \pm 151$ \\
\hline \multicolumn{3}{|c|}{ Human Milk Oligosaccharides } \\
\hline H0400 & Gal- $\beta-1,4-G l c-S p$ & $1044 \pm 110$ \\
\hline
\end{tabular}

Glc = glucose; Gal = galactose; Man = mannose; GlcNAc = N-acetyl-D-glucosamine; GalNAc = N-acetyl-D-galactosamine; Fuc $=$ Fucose. 
Biomolecules 2020, 10, 333

9 of 15
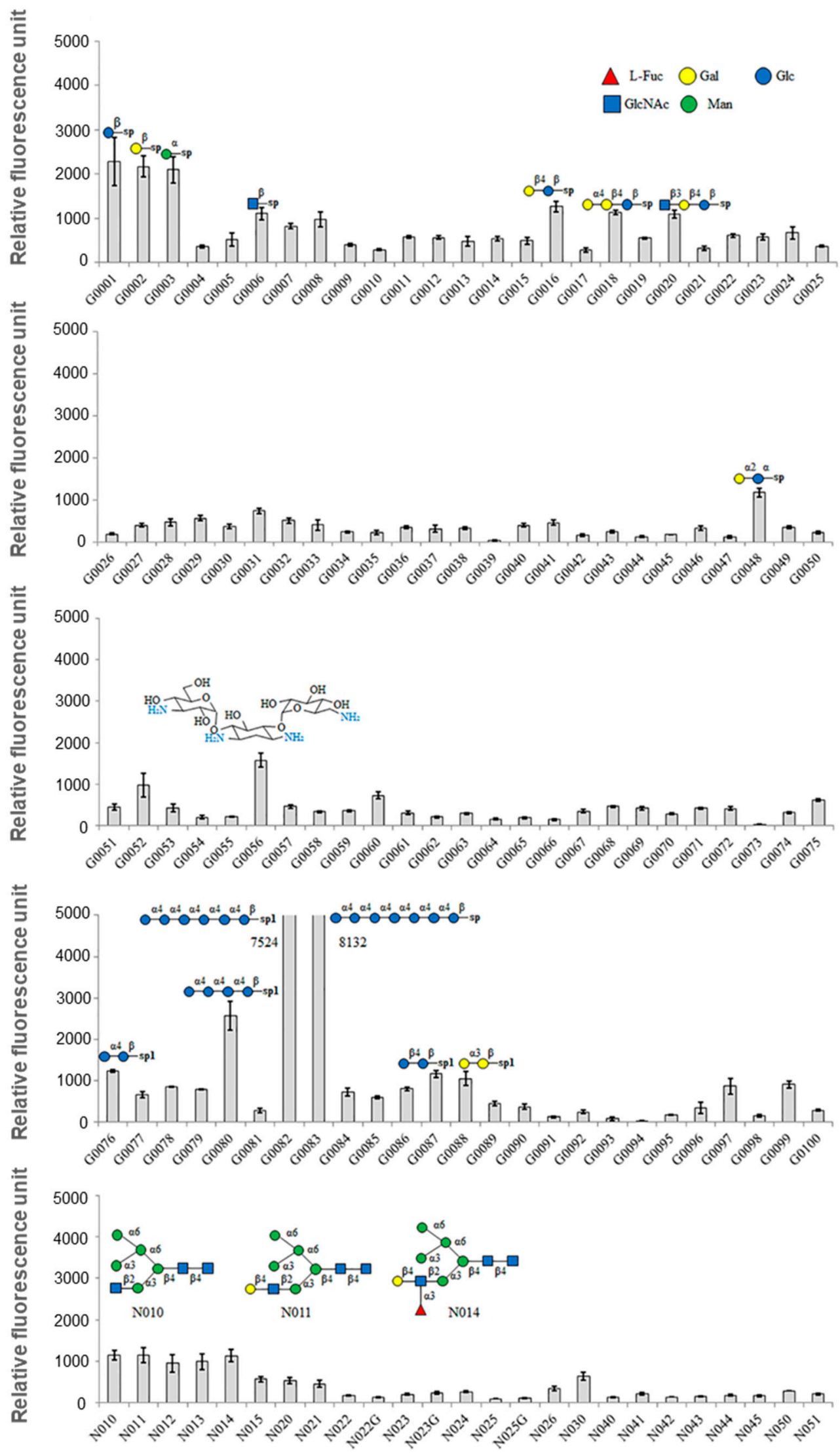

Figure 4. Glycan array of Grateloupia chianggi lectin. Relative fluorescence units were calculated using an array analysis program (RayBioTech). The glycan structure is given for signals that exceeded 1000 relative fluorescence units. Error bars represent mean \pm standard deviation (SD) of triplicate experiments. 


\subsection{Antiviral Activity of GCL}

The antiviral activity of GCL was screened against the influenza virus (PR8, HK, and Lee type), HIV type 1, and herpes (HSV1 and HSV2). GCL was effective against the influenza virus and HSV (Table 5, Table 6) but was not effective against HIV. Influenza infection was successfully inhibited by GCL treatment at $1.37 \mu \mathrm{M}$ (H1N1), $0.95 \mu \mathrm{M}$ (H3N2), and $1.05 \mu \mathrm{M}$ (Flu B) (Table 5). The antiviral effect was more pronounced against HSV, with an $\mathrm{EC}_{50}$ of $0.0001-0.0152 \mu \mathrm{M}$ of GCL (Table 6). However, GCL did not inhibit HIV infection at any concentration tested. GCL showed no toxicity to cell lines at the tested concentrations.

Table 5. Antiviral activity of Grateloupia chianggi lectin (GCL) against influenza virus strains.

\begin{tabular}{ccccc}
\hline \multirow{2}{*}{ Compounds } & & \multicolumn{2}{c}{ EC $_{\mathbf{5 0}}(\mu \mathrm{M})$ Against Influenza Viruses (SI) } \\
\cline { 3 - 5 } & CC50 $(\mu \mathrm{M})$ in & \multicolumn{2}{c}{ Flu A } & Flu B \\
\cline { 3 - 5 } & MDCK Cells & $\begin{array}{c}\text { Puerto Rico/8/34 } \\
\mathbf{( H 1 N 1 )}(\mathbf{P R 8})\end{array}$ & $\begin{array}{c}\text { Hong Kong/8/68 } \\
\text { (H3N2) (HK) }\end{array}$ & Lee/1940 (B) \\
\hline GCL & $>1.6^{£}$ & $1.37 \pm 0.31(\mathrm{ND})$ & $0.95 \pm 0.09(\mathrm{ND})$ & $1.05 \pm 0.2(\mathrm{ND})$ \\
OSV-C & $>100.0$ & $0.071 \pm 0.01$ & $<0.004 \pm 0.0004$ & $1.83 \pm 0.18(>54.5)$ \\
AMT & $>100.0$ & $>100.0(\mathrm{ND})$ & $13.2 \pm 3.5(>7.5)$ & $>100.0(\mathrm{ND})$ \\
RBV & $>100.0$ & $18.88 \pm 2.17(>5.3)$ & $19.22 \pm 3.89(>4.6)$ & $\begin{array}{c}18.14 \pm 0.71 \\
(>138.1)\end{array}$ \\
\hline
\end{tabular}

${ }^{£}$ Maximum concentration of GCL that could be prepared. SI = selectivity index [ratio of CC50 (50\% cytotoxic concentration) to $\mathrm{EC}_{50}(50 \%$ effective concentration)]; $\mathrm{ND}=$ not determined; $\mathrm{AMT}=$ amantadine hydrochloride; $\mathrm{RBV}=$ ribavirin; OSV-C, $=$ oseltamivir carboxylate.

Table 6. Antiviral activity of Grateloupia chianggi lectin (GCL) against herpes simplex virus (HSV).

\begin{tabular}{cccccc}
\hline & \multirow{2}{*}{ Toxicity $\mathrm{CC}_{\mathbf{5 0}}$} & \multicolumn{2}{c}{ Antiviral Activity $\left(\mathbf{E C}_{\mathbf{5 0}}\right), \boldsymbol{\mu M}$} & \multicolumn{2}{c}{ Selective Index } \\
\cline { 3 - 6 } & & HSV1 (F) & HSV2 (MS) & HSV1 (F) & HSV2 (MS) \\
\hline GCL & $>1.6$ & 0.0152 & 0.00144 & $>1.12$ & $>5.6$ \\
Acyclovir & $>100$ & $0.52^{£}$ & $2.87 £$ & $>192$ & $>35$ \\
Penosan polysulfate & $>100$ & 4.77 & 2.10 & 21 & $>48$ \\
\hline \multicolumn{4}{c}{${ }^{£}$ Maximum concentration of GCL that could be prepared. }
\end{tabular}

\section{Discussion}

A novel D-mannose-binding lectin (GCL) from the red alga, G. chiangii, was successfully purified and molecularly characterized. In the current literature, many red algal lectins have been screened by hemagglutination tests but few have been purified and molecularly characterized. In the present study, mannose affinity chromatography was a powerful tool for the purification of GCL from whole cell extracts. Approximately $5 \mathrm{mg}$ of protein were obtained from $10 \mathrm{~g}$ of plants. The yield of lectin from G. chiangii was moderate compared to other algal lectins, such as that from Aglaothamnion callophyllidicola [21].

GCL was identified as a mannose-binding lectin, with a molecular weight of $\sim 25 \mathrm{kDa}$ by SDS-PAGE. The estimated molecular weight corresponded to molecular weights calculated from the deduced amino acid sequences. The N-terminal amino acid sequence determined by Edman degradation exactly matched the deduced amino acid sequence. The N-terminal methionine of GCL was eliminated during post-modification of the protein. N-terminal methionine excision is a conserved pathway in all compartments where protein synthesis occurs [33]. About $70 \%$ of peptide fragments that were discovered by MS/MS spectrometry were covered by the protein sequence.

Interestingly, GCL showed an absence of cysteine residues in its amino acid sequence, suggesting that GCL is a monomeric protein rather than a multimeric protein. GCL possessed a tandem repeat structure which consisted of six domains. Generally, the monomeric form of red algal lectin structures is 
distinguishable from land plants or animals, which are multimeric and are connected by disulfide bonds or other chemical interactions [21]. Similar to other red algal lectins that have short peptide $(\sim 30$-mer) tandem repeat structures [18], GCL possessed a repeat structure in its primary structure. This may contribute to the stability of lectin's tertiary structure and may be a substitute for the advantages conferred through multimeric structures [18,34]. The tandem repeat structure of GCL was considered to be preferable for our purposes, as this is shared with other red algal lectins and may contribute to an increase in hemagglutination activity $[18,23,34]$. Furthermore, the isolated GCL amino acid sequence interestingly represented high similarity with bacterial lectins as shown in Supplementary Figure S4. We considered these results are derived from the lack of sequence information concerning red algal lectins in the NCBI database. Also, whereas prokaryotic lectins usually not contain poly-A sequences, the eukaryotic lectins represent poly-A amino acid sequences as shown in Figure S1, and thus we considered GCL is an algal lectin.

The hemagglutination activity of GCL did not require divalent ions. It was also shown that GCL possessed no heat tolerance, which may be caused by a lack of cysteine residues, even though $20 \%$ of activity remained after exposure to $90^{\circ} \mathrm{C}$ for $30 \mathrm{~min}$. The temperature range for heat stability of red algal lectins is wide, varying from 30 to $100{ }^{\circ} \mathrm{C}$ [17], with most falling between 30 and $50{ }^{\circ} \mathrm{C}$ [17]. In the case of Gracilaria ornata lectin, activity was not lost until $50^{\circ} \mathrm{C}$ [35]. G. ornata lectin is made up of at least $7.79 \%$ cysteine residues while GCL possesses no cysteine. Lack of cysteine residues results in hydrogen or ionic interactions in protein structures being easily broken, but intra-molecular disulfide bonds may retain structural stability through covalent bonds in G. ornata lectin [35].

The isolated GCL specifically agglutinated horse blood cells, but not sheep blood cells. Isolated GCL was inhibited by D-mannose and fructose as well as the glycoprotein, fetuin. However, as hemagglutination inhibition tests do not reflect diverse glycans, a glycan array was used to determine the glycan recognition properties of GCL. Among 300 glycans, 18 glycans demonstrated a positive signal over 1000 RFU. Similar to the inhibition test results, GCL showed specificity toward $\alpha$-Man. In contrast to the inhibition test, binding properties differed for the alpha $(\alpha-)$ and beta $(\beta-)$ conformations of sugars, i.e., glucose and galactose. Only $\alpha$-conformation monosaccharides were used in the inhibition test, and as such, it can be assumed that GCL demonstrates stereoisomerism with regard to the sugar-lectin binding. With the exception of a few red algal lectins such as the lectins from Hypnea cervicornis [36], Hypnea musciformis [37] and Vidalia obtusiloba [38], most lectins are specific for glycoproteins such as mucin and fetuin. The glycan composition and validated proteoforms of bovine fetuin is previously well-described by comparing with human fetuin and recombinant human fetuin [39].

Glycoprotein specific lectins are more complicated to use in research or medical applications than those that are specific to monosaccharides because of the difficulty in predicting their reactivity. GCL was able to bind not only to monosaccharides but also to glycoproteins. The previous review has reported that a lot of algal lectins, especially from red algae, commonly have distinct characteristics compared to those of terrestrial plants such as low molecular weight, monomeric form, high thermostability, an affinity for glycoproteins but not for monosaccharides, and no divalent cations requirements [40]. However, interestingly, GCL represented affinities for specific monosaccharide including D-mannose and fructose (Table 3). Similar to GCL, monosaccharide-binding lectins are also reported from several algae such as Enteromorpha sp. [41] and Ulva sp. [42]. Also, the previous report showed that HIV inhibiting algal lectins usually exhibit high mannose-binding property. However, no HIV-inhibiting activity was observed from purified GCL. Based on the results, we concluded the GCL is novel algal lectins showing distinct nature than the other reported algal lectins.

GCL possessed the highest specificity for Maltotetraose- $\beta$, Maltohexaose- $\beta$, and Maltoheptaose- $\beta$. As the length of the sugar chain increased, the signal likewise increased. The reason behind this difference in signal intensity is not straightforward, but the assumption is that a greater number of GCLs were bound to these longer chains rather than there being a difference in the binding strength between lectin and sugars as the length of the sugar chain increases. 
Additionally, GCL could bind to high-mannan N-glycans that are related to antiviral abilities. With this sugar specificity, GCL's antiviral activity could be assumed because the antiviral activities of other mannose-binding lectins have already been reported [43]. In addition to these antiviral properties, anti-cancer properties of mannose-binding lectins have also been reported in marine algae $[16,17]$.

The antiviral effect have been reported by lectins derived from diverse organisms including prokaryotic organisms (Microcystis viridis lectin, cyanovirin-N, actinohivin, scytovirin, and etc.), plants (Jacalin, BanLec, Griffithsin, Scilla campanulata lectin, Narcissus pseudonarcissus lectin, Galanthus nivalis agglutinin, and etc.), and marine eukaryotic organisms (Chaetopterus variopedatus lectin, Serpula vermicularis lectin, Crenomytilus grayanus lectin, and etc.) [13]. The mechanism of antiviral activity of lectins has been well-described by previous review [13]. According to the report, a lot of lectins derived from bacteria, plants, and marine algae effectively suppress the viral replication by reacting with envelope glycoproteins [13]. A common viral recognition and entry regulated by a specific protein called "glycosylated envelope proteins (GEP)." A GEP usually has affinity for cell-surface proteins of host cells, and existing antiviral lectins react with high-mannose glycan structures, and thus trigger post-translational modifications of viral GEP. For instance, a GEP complex of HIV (Env complex) is composed of the transmembrane trimer of gp31 and the extracellular trimer of gp120 containing N-linked oligosaccharide attachment sites. These structures assist viral evasion of the host immune system and entry into the host cells mediated by recognition of $\mathrm{CD} 4^{+}$triggering a cascade of conformational rearrangement of Env complex. The antiviral lectins inhibit conformational reorganization of the Env complex, and thus lead to suppressed viral fusion into host cells [13].

Our preliminary tests demonstrated an antiviral activity of GCL against the influenza virus and HSV but not against HIV. GCL was more effective against HSV than the influenza virus, requiring only 1 to $20 \mathrm{nM}$ to inhibit HSV infection. The antiviral activities of 12 different lectins were tested and the ESA-2 lectin had an $\mathrm{EC}_{50}$ of $12.4 \mathrm{nM}[44,45]$. ESA-2 specifically recognizes high mannose N-glycans, similarly to GCL. Inhibition of viral infection by ESA-2 is intermediated by blocking viral binding to a critical portion of the target cell, because certain high mannose glycan(s) are present on the region of the virus surface involved in receptor binding [40,41]. GCL had antiviral activities 100 times $(1.37 \mu \mathrm{M})$ lower than ESA-2 and AAL [44,45]. Although GCL was less effective against influenza than ESA-2, GCL represented comparable values to the positive controls, RBV and AMT. GCL was also able to bind to high mannose $\mathrm{N}$-glycans, thus we hypothesize that it may inhibit viral infections by similar mechanisms of ESA-2. However, the elucidation of these mechanisms will require comprehensive studies on GCL and viral interactions.

In this study, a novel mannose-binding lectin from the red alga, G. chiangii, was obtained and termed GCL. The antiviral activity of this lectin was tested and was determined to be a prospective antiviral agent.

\section{Conclusions}

Mannose-binding lectin from the red alga, G. chiangii was purified and termed GCL. GCL specifically bound the monosaccharides, $\beta$-Glc-sp, $\beta$-Gal-sp, and $\alpha$-Man-sp, and possessed a strong affinity for Maltohexaose- $\beta$-Sp1 and Maltoheptaose- $\beta$-Sp1. High-mannan structures such as Man- $\alpha-1,6-($ Man- $\alpha-1,3-)$ Man- $\alpha-1,6-(G l c N A c-\beta-1,2-M a n-\alpha-1,3-)$ Man- $\beta-1,4-G l c N A c-\beta-1,4-G l c N A c-S p 5$ also interact with GCL. Based on this carbohydrate specificity, an antiviral property of GCL was suggested, and indeed, purified lectin had an antiviral activity against the influenza virus and HSV.

Supplementary Materials: The supplementary materials are available online at http://www.mdpi.com/2218-273X/ 10/2/333/s1.

Author Contributions: H.-J.H. drafted the manuscript and contributed to the discussion with valuable idea. J.-W.H., H.J., and J.-h.K. performed all the experiments and analyzed the data. K.C. and D.-S.L. contributed to data interpretation and provided reviews. J.W.H. designed all the experiments and supervised the experiments, and contributed to the funding. All authors have read and agreed to the published version of the manuscript. 
Funding: This research was supported by a grant from National Marine Biodiversity Institute Research Program (2020M00600).

Conflicts of Interest: The authors declare no conflict of interest.

\section{Abbreviations}

$\begin{array}{ll}\text { GCL } & \text { G. chianggi lectin } \\ \text { TBS } & \text { Tris-buffered saline } \\ \text { Man } & \text { D-mannose } \\ \text { DTT } & \text { 1,4-Dithiothreitol } \\ \text { PBS } & \text { phosphate buffered saline } \\ \text { Glc } & \text { D-glucose } \\ \text { Gal } & \text { D-galactose } \\ \text { GlcNAc } & \text { N-acetyl-D-glucosamine } \\ \text { MDCK } & \text { Madin-Darby canine kidney } \\ \text { ATCC } & \text { American Type Culture Collection } \\ \text { ATCC } & \text { African green monkey kidney Vero cells } \\ \text { HSV } & \text { herpes simplex virus } \\ \text { HIV } & \text { human immunodeficiency virus } \\ \text { PR8 } & \text { A/Puerto Rico/8/34 } \\ \text { HK } & \text { A/Hong Kong/8/68 } \\ \text { TPCK } & \text { L-1-Tosylamide-2-phenylethyl chloromethyl ketone-trypsin } \\ \text { MTT } & \text { 3-(4,5-dimethylthiazol-2-yl)-2,5-diphenyltetrazolium bromide } \\ \text { CC } 50 & \text { The 50\% cytotoxic concentration } \\ \text { EC } 50 & \text { the 50\% effective concentration } \\ \text { GEP } & \text { glycosylated envelope proteins } \\ \end{array}$

\section{References}

1. Sharon, N.; Lis, H. History of lectins: From hemagglutinins to biological recognition molecules. Glycobiology 2004, 14, 53-62. [CrossRef]

2. Goldstein, I.J.; Hughes, R.C.; Monsigny, M.; Osawa, T.; Sharon, N. What should be called a lectin? Nature 1980, 285, 66. [CrossRef]

3. Berg, J.M.; Tymoczko, J.L.; Stryer, L. Section 11.4 Lectins Are Specific Carbohydrate-Binding Proteins. In Biochemistry, 5th ed.; W. H. Freeman: New York, NY, USA, 2002; pp. 1-3.

4. Takahashi, K.; Ezekowitz, R.A.B. The role of the mannose-binding lectin in innate immunity. Clin. Infect. Dis. 2005, 41, 440-444. [CrossRef]

5. Matsumoto, J.; Nakamoto, C.; Fujiwara, S.; Yubisui, T.; Kawamura, K. A novel C-type lectin regulating cell growth, cell adhesion and cell differentiation of the multipotent epithelium in budding tunicates. Development 2001, 128, 3339-3347.

6. Lis, H.; Sharon, N. Lectins as molecules and as tools. Annu. Rev. Biochem. 1986, 55, 35-67. [CrossRef]

7. Mody, R.; Joshi, S.; Chaney, W. Use of lectins as diagnostic and therapeutic tools for cancer. J. Pharmacol. Toxicol. Methods 1995, 33, 1-10. [CrossRef]

8. Dan, X.; Ng, T.B.; Wong, J.H.; Chan, Y.S.; Cheung, R.C.F.; Chan, W.Y. A hemagglutinin isolated from Northeast China black beans induced mitochondrial dysfunction and apoptosis in colorectal cancer cells. Biochim. Biophys. Acta 2016, 1863, 2201-2221. [CrossRef]

9. Guasch, R.M.; Guerri, C.; O'Connor, J.E. Study of surface carbohydrates on isolated Golgi subfractions by fluorescent-lectin binding and flow cytometry. Cytometry 1995, 19, 112-118. [CrossRef]

10. Freeze, H.H. Lectin affinity chromatography. Curr. Protoc. Protein Sci. 2001, 9. [CrossRef]

11. Hu, S.; Wong, D.T. Lectin microarray. Proteomics Clin. Appl. 2009, 3, 148-154. [CrossRef]

12. Lavín de Juan, L.; García Recio, V.; Jiménez López, P.; Girbés Juan, T.; Cordoba-Diaz, M.; Cordoba-Diaz, D. Pharmaceutical applications of lectins. J. Drug Deliv. Sci. Technol. 2017, 42, 126-133.

13. Mitchell, C.A.; Ramessar, K.; O'Keefe, B.R. Antiviral lectins: Selective inhibitors of viral entry. Antiviral Res. 2017, 142, 37-54. [CrossRef] 
14. Yau, T.; Dan, X.; Ng, C.C.W.; Ng, T.B. Lectins with potential for anti-cancer therapy. Molecules 2015, 20, 3791-3810. [CrossRef]

15. Poiroux, G.; Barre, A.; van Damme, E.J.M.; Benoist, H.; Rougé, P. Plant Lectins Targeting O-Glycans at the Cell Surface as Tools for Cancer Diagnosis, Prognosis and Therapy. Int. J. Mol. Sci. 2017, 18, 1232. [CrossRef]

16. Singh, R.S.; Thakur, S.R.; Bansal, P. Algal lectins as promising biomolecules for biomedical research. Crit. Rev. Microbiol. 2015, 41,77-88. [CrossRef]

17. Singh, R.; Walia, A. Lectins from red algae and their biomedical potential. J. Appl. Phycol. 2018, 30, 1833-1858. [CrossRef]

18. Hwang, H.-J.; Han, J.-W.; Jeon, H.; Han, J.W. Induction of Recombinant Lectin Expression by an Artificially Constructed Tandem Repeat Structure: A Case Study Using Bryopsis plumosa Mannose-Binding Lectin. Biomolecules 2018, 8, 146. [CrossRef]

19. Lusvarghi, S.; Bewley, C.A. Griffithsin: An Antiviral Lectin with Outstanding Therapeutic Potential. Viruses 2016, 8, 296. [CrossRef]

20. Lee, C. Griffithsin, a Highly Potent Broad-Spectrum Antiviral Lectin from Red Algae: From Discovery to Clinical Application. Mar. Drugs 2019, 17, 567. [CrossRef]

21. Shim, E.; Shim, J.; Klochkova, T.A.; Han, J.W.; Kim, G.H. Purification of a sex-specific lectin involved in gamete binding of Aglaothamnion callophyllidicola (Rhodophyta)(I). J. Phycol. 2012, 48, 916-924. [CrossRef]

22. Han, J.W.; Klochkova, T.A.; Shim, J.B.; Yoon, K.; Kim, G.H. Isolation and characterization of a sex-specific lectin in a marine red alga, Aglaothamnion oosumiense Itono. Appl. Environ. Microbiol. 2012, 78, 7283-7289. [CrossRef] [PubMed]

23. Hwang, H.-J.; Han, J.-W.; Kim, G.H.; Han, J.W. Functional Expression and Characterization of the Recombinant N-Acetyl-Glucosamine/N-Acetyl-Galactosamine-Specific Marine Algal Lectin BPL3. Mar. Drugs 2018, 16, 13. [CrossRef] [PubMed]

24. Zhang, W.; van Eijk, M.; Guo, H.; van Dijk, A.; Bleijerveld, O.B.; Verheije, M.H.; Wang, G.; Haagsman, H.P.; Veldhuizen, E.J.A. Expression and characterization of recombinant chicken mannose binding lectin. Immunobiology 2017, 222, 518-528. [CrossRef]

25. Liu, Y.; Liu, J.; Pang, X.; Liu, T.; Ning, Z.; Cheng, G. The roles of direct recognition by animal lectins in antiviral immunity and viral pathogenesis. Molecules 2015, 20, 2272-2295. [CrossRef]

26. Michelow, I.C.; Lear, C.; Scully, C.; Prugar, L.I.; Longley, C.B.; Yantosca, L.M.; Ji, X.; Karpel, M.; Brudner, M.; Takahashi, K.; et al. High-dose mannose-binding lectin therapy for Ebola virus infection. J. Infect. Dis. 2011, 203, 175-179. [CrossRef]

27. Watson, B.A.; Waaland, S.D. Partial Purification and Characterization of a Glycoprotein Cell Fusion Hormone from Griffithsia pacifica, a Red Alga. Plant Physiol. 1983, 71, 327-332. [CrossRef]

28. Mori, T.; O'Keefe, B.R.; Sowder, R.C.; Bringans, S.; Gardella, R.; Berg, S.; Cochran, P.; Turpin, J.A.; Buckheit, R.W.; McMahon, J.B.; et al. Isolation and characterization of griffithsin, a novel HIV-inactivating protein, from the red alga Griffithsia sp. J. Biol. Chem. 2005, 280, 9345-9353. [CrossRef]

29. Meuleman, P.; Albecka, A.; Belouzard, S.; Vercauteren, K.; Verhoye, L.; Wychowski, C.; Leroux-Roels, G.; Palmer, K.E.; Dubuisson, J. Griffithsin has antiviral activity against hepatitis C virus. Antimicrob. Agents Chemother. 2011, 55, 5159-5167. [CrossRef]

30. Han, J.W.; Jung, M.G.; Kim, M.J.; Yoon, K.S.; Lee, K.P.; Kim, G.H. Purification and characterization of a D-mannose specific lectin from the green marine alga, Bryopsis plumosa. Phycol. Res. 2010, 58, 143-150. [CrossRef]

31. Kruger, N.J. The Bradford Method For Protein Quantitation. In The Protein Protocols Handbook; Walker, J.M., Ed.; Springer Protocols Handbooks; Humana Press: Totowa, NJ, USA, 2009; pp. 17-24.

32. Kim, M.; Kim, S.-Y.; Lee, H.W.; Shin, J.S.; Kim, P.; Jung, Y.-S.; Jeong, H.-S.; Hyun, J.-K.; Lee, C.-K. Inhibition of influenza virus internalization by (-)-epigallocatechin-3-gallate. Antiviral Res. 2013, 100, 460-472. [CrossRef]

33. Giglione, C.; Vallon, O.; Meinnel, T. Control of protein life-span by N-terminal methionine excision. EMBO J. 2003, 22, 13-23. [CrossRef] [PubMed]

34. Han, J.W.; Jung, M.G.; Shim, E.Y.; Shim, J.B.; Kim, Y.M.; Kim, G.H. Functional recombinants designed from a fetuin/asialofetuin-specific marine algal lectin, rhodobindin. Mar. Drugs 2015, 13, 2183-2195. [CrossRef] [PubMed] 
35. Leite, Y.F.; Silva, L.M.; Amorim, R.C.; Freire, E.A.; de Melo Jorge, D.M.; Grangeiro, T.B.; Benevides, N.M. Purification of a lectin from the marine red alga Gracilaria ornata and its effect on the development of the cowpea weevil Callosobruchus maculatus (Coleoptera: Bruchidae). Biochim. Biophys. Acta 2005, 1724, 137-145. [CrossRef]

36. Nascimento, K.S.; Nagano, C.S.; Nunes, E.V.; Rodrigues, R.F.; Goersch, G.V.; Cavada, B.S.; Calvete, J.J.; Saker-Sampaio, S.; Farias, W.R.L.; Sampaio, A.H. Isolation and characterization of a new agglutinin from the red marine alga Hypnea cervicornis J. Agardh. Biochem. Cell Biol. 2006, 84, 49-54. [CrossRef]

37. Nagano, C.S.; Gallego del Sol, F.; Cavada, B.S.; Nascimento, K.S.D.; Nunes, E.V.; Sampaio, A.H.; Calvete, J.J. Crystallization and preliminary X-ray diffraction analysis of HML, a lectin from the red marine alga Hypnea musciformis. Acta Crystallogr. Sect. F Struct. Biol. Cryst. Commun. 2005, 61, 997-999. [CrossRef]

38. Melo, F.; Benevides, N.; Pereira, M.; Holanda Araújo, M.; Mendes, F.; Oliveira, S.; Freitas, A.; Silva, L. Purification and partial characterisation of a lectin from the red marine alga Vidalia obtusiloba C. Agardh. J. Bot. 2004, 27, 263-269. [CrossRef]

39. Lin, Y.H.; Franc, V.; Heck, A.J. Similar albeit not the same: In-depth analysis of proteoforms of human serum, bovine serum, and recombinant human fetuin. J. Proteome Res. 2018, 17, 2861-2869. [CrossRef] [PubMed]

40. Praseptiangga, D. Algal lectins and their potential uses. Squalen 2015, 10, 89-98. [CrossRef]

41. Ambrosio, A.L.; Sanz, L.; Sánchez, E.I.; Wolfenstein-Todel, C.; Calvete, J.J. Isolation of two novel mannan-and L-fucose-binding lectins from the green alga Enteromorpha prolifera: Biochemical characterization of EPL-2. Arch. Biochem. Biophys. 2003, 415, 245-250. [CrossRef]

42. Wang, S.; Zhong, F.D.; Zhang, Y.J.; Wu, Z.J.; Lin, Q.Y.; Xie, L.H. Molecular characterization of a new lectin from the marine alga Ulva pertusa. Acta Biochem. Biophs. Sin. 2004, 36, 111-117. [CrossRef]

43. Turner, M.W. The role of mannose-binding lectin in health and disease. Mol. Immunol. 2003, 40, 423-429. [CrossRef]

44. Sato, Y.; Morimoto, K.; Kubo, T.; Sakaguchi, T.; Nishizono, A.; Hirayama, M.; Hori, K. Entry Inhibition of Influenza Viruses with High Mannose Binding Lectin ESA-2 from the Red Alga Eucheuma serra through the Recognition of Viral Hemagglutinin. Mar. Drugs 2015, 13, 3454-3465. [CrossRef]

45. Reading, P.C.; Miller, J.L.; Anders, E.M. Involvement of the mannose receptor in infection of macrophages by influenza virus. J. Virol. 2000, 74, 5190-5197. [CrossRef] 